\title{
Investigations on anopheline mosquitoes close to the nest sites of chimpanzees subject to malaria infection in Ugandan Highlands
}

Sabrina Krief ${ }^{1,2^{*}}$, Florence Levrero ${ }^{3}$, Jean-Michel Krief ${ }^{2}$, Supinya Thanapongpichat ${ }^{4}$, Mallika Imwong ${ }^{4}$, Georges Snounou ${ }^{5,6}$, John M Kasenene ${ }^{7}$, Marie Cibot $^{1}$ and Jean-Charles Gantier ${ }^{8}$

\begin{abstract}
Background: Malaria parasites (Plasmodium sp.), including new species, have recently been discovered as low grade mixed infections in three wild chimpanzees (Pan troglodytes schweinfurthii) sampled randomly in Kibale National Park, Uganda. This suggested a high prevalence of malaria infection in this community. The clinical course of malaria in chimpanzees and the species of the vectors that transmit their parasites are not known. The fact that these apes display a specific behaviour in which they consume plant parts of low nutritional value but that contain compounds with anti-malarial properties suggests that the apes' health might be affected by the parasite. The avoidance of the night-biting anopheline mosquitoes is another potential behavioural adaptation that would lead to a decrease in the number of infectious bites and consequently malaria.
\end{abstract}

Methods: Mosquitoes were collected over two years using suction-light traps and yeast-generated $\mathrm{CO}_{2}$ traps at the nesting and the feeding sites of two chimpanzee communities in Kibale National Park. The species of the female Anopheles caught were then determined and the presence of Plasmodium was sought in these insects by PCR amplification.

Results: The mosquito catches yielded a total of 309 female Anopheles specimens, the only known vectors of malaria parasites of mammalians. These specimens belonged to 10 species, of which Anopheles implexus, Anopheles vinckei and Anopheles demeilloni dominated. Sensitive DNA amplification techniques failed to detect any Plasmodium-positive Anopheles specimens. Humidity and trap height influenced the Anopheles capture success, and there was a negative correlation between nest numbers and mosquito abundance. The anopheline mosquitoes were also less diverse and numerous in sites where chimpanzees were nesting as compared to those where they were feeding.

Conclusions: These observations suggest that the sites where chimpanzees build their nests every night might be selected, at least in part, in order to minimize contact with anopheline mosquitoes, which might lead to a reduced risk in acquiring malaria infections.

Keywords: Malaria, Chimpanzee, Anopheles, Plasmodium, Kibale national park, Nesting behaviour

\footnotetext{
* Correspondence: krief@mnhn.fr

'UMR 7206- Eco-anthropologie et ethnobiologie, Muséum National d'Histoire Naturelle, Paris, France

${ }^{2}$ Projet pour la Conservation des Grands Singes, Paris, France

Full list of author information is available at the end of the article
} 


\section{Background}

The closest relatives to human beings, chimpanzees, gorillas and orang-utans, are under threat of extinction because of dwindling habitats. The survival of the remaining populations is highly sensitive to the spread of diseases [1]. Great apes are genetically very close to humans and this means that they are susceptible to infection by a variety of pathogens of humans, including bacteria, virus and parasites [2-13]. In this context, malaria is of particular interest. Malaria, a disease that results from infection by a protozoan parasite of the genus Plasmodium, is a major global public health problem that undermines development in the poorest countries. For example, in 2008 more than 247 millions cases and one million deaths attributable to malaria were recorded [14]. Three Plasmodium species, morphologically very similar to the parasites that infect humans (Plasmodium vivax or Plasmodium ovale, Plasmodium malariae and Plasmodium falciparum), have been described early in the $20^{\text {th }}$ century in wild African great apes (chimpanzees, bonobos and gorillas): Plasmodium schwetzi, Plasmodium rodhaini, and Plasmodium reichenowi, respectively $[15,16]$. Two recent molecular surveys of DNA purified from blood samples collected from two chimpanzees kept as pets in Gabon [17], or from three of eight chimpanzees recovered from poachers in the Democratic Republic of Congo (DRC) and in all three wild chimpanzees sampled from Kibale National Park, Uganda [12], uncovered the presence of three more Plasmodium species closely related to P. falciparum. The fact that all the three chimpanzees sampled randomly among a group of 44 individuals of the Kanyawara community were positive and carried mixed infections suggested that prevalence of the infection might be high in nature. Further surveys conducted on material derived from a large collection of faeces from wild great apes, confirmed the diversity of the parasites in chimpanzees, revealed three additional species related to $P$. falciparum in gorillas, and reinforced the notion that the parasite prevalence could be very high in some communities [18-21]. It is interesting to note that great apes are also susceptible to infection by the parasites of humans. Thus, P. falciparum and P. malariae were detected in bonobos, cared for in a sanctuary in the Democratic Republic of Congo located within a suburb of Kinshasa, that is endemic for human malaria [12], P. ovale was detected in two chimpanzees from Cameroon [22], and finally $P$. malariae was found in two chimpanzees imported to Japan 30 years previously [23]. Thus, African great apes harbour a diverse collection of malaria parasites, and are susceptible to infection by those that infect humans.

Kibale National Park (NP) is located in the western highlands of Uganda. The human population in these districts is subjected to malaria such that Plasmodium infections are the most common cause of illness (e.g. [24]), as is typically observed in many of the highland districts of Uganda or other sub-Saharan countries [25-35]. It is interesting that malaria has not been recorded as a disease, during extensive long-term monitoring of great apes at Kibale NP and at numerous other research sites. This contrasts with observations of humans in malaria endemic areas. Whether the absence of observed symptoms in wild chimpanzees rests with the substantial difficulties associated with close health monitoring, or to an inherent clinical tolerance in infected apes, or both, remains to be established. The fact that a restricted number of captive chimpanzees experimentally infected in the 1930s and 1940 s by a variety of Plasmodium species did not suffer severe clinical symptoms $[15,16]$ does not exclude the possibility that chimpanzees experience clinical malaria.

The apparent absence of clinical malaria in natural communities might also be due to non-physiological factors. Two behavioural adaptations might lead to a reduction in malaria. Previous studies have revealed that great apes occasionally consume small amounts of selected parts from several plant species, that have no nutritive value but which contain bio-active compounds with anti-parasitic properties [36-47], including two from Trichilia rubescens leaves that are active against Plasmodium $[48,49]$. This provides a tantalizing suggestion that these animals do indeed experience discomfort as a result of malarial infection, which they then seek to alleviate by ingesting specific plants. A second behavioural adaptation would be one of mosquito avoidance. At present, the natural vectors of the parasites that infect the African great apes are not known. All attempts to transmit $P$. reichenowi experimentally by Anopheles gambiae, Anopheles maculipennis, Anopheles atroparvus, Anopheles balabacensis, Anopheles freeborni and Anopheles stephensi, failed consistently [16,50-52]. Given the probable high endemicity of malaria in the Kibale chimpanzees, it was felt that investigations of the Anopheles mosquitoes in the home ranges of the Kanyawara chimpanzee might help to gather indications whether chimpanzee behaviour alters the nature of the chimpanzeemosquito contact. It was further hoped that it might also identify which Anopheles species naturally transmit Plasmodium to chimpanzees. Given that the biting activity in female Anopheles generally occurs at night and that proximity of swamp and small variation of temperature may increase malaria risk [53], the present study tested the hypothesis that the choice of chimpanzees for the location and height of their nesting sites may be influenced by the presence of potential vectors of infectious diseases.

\section{Methods}

Study site

Chimpanzee monitoring and mosquito collections were conducted in both Kanyawara and Kanyanchu areas, in 
Kibale NP, Western Uganda (0 13'-0 41'N and 30 19'-30 $\left.32^{\prime} \mathrm{E}\right)$. Kibale NP covers an area of $795 \mathrm{~km}^{2}$ of mildaltitude forest with high biodiversity, most likely because it was a Pleistocene refugium [54]. The area comprises mostly lowland rain forest, montane forest, mixed deciduous forest $(57 \%)$, colonizing forest (19\%), lake and wetlands $(2 \%)$ with some grassland (15\%), and exotic trees plantations (1\%) [55]. Some forestry compartments were selectively harvested during the late 1960s [56]. Areas where agricultural activities predominate surround the National Park, thus $58 \%$ of the land within $1.4 \mathrm{~km}$ of the park boundary is used for smallholder agriculture (Mugisha, 1994 cited by [57]).

\section{Behavioural and clinical observations}

Data and mosquitoes were collected in the home ranges of two habituated chimpanzee communities of Kanyawara (44 chimpanzees) and Kanyanchu (120 chimpanzees) in Kibale NP, Uganda. Chimpanzee parties (labile sub-groups of the community in the fission-fusion social system of chimpanzees) were followed daily from nest to nest. Observers were very careful not to disturb chimpanzee behaviour and followed the research proposal reviewed and approved by Uganda Wildlife Authority. Tree species and type of habitat (primary forest or secondary forest) used for nesting, nest height as well as the number and identity of chimpanzees under observation were recorded.

\section{Ecology and identification of Anopheles species in the chimpanzees' environment}

Mosquitoes were collected throughout the period extending from January 2006 to January 2008 in Kanyawara and from May to July 2009 in Kanyanchu (dry season) using suction light traps (adapted from [58]). At each collection, two traps were used following a protocol (Table 1) designed to optimize the trapping and the understanding of mosquito ecology, the mosquito attractant $\mathrm{CO}_{2}$ [59] was generated by yeast converting sugar in alcohol. The yeastglucose solution (100 g glucose $+6 \mathrm{~g}$ dry yeast in $1.5 \mathrm{l}$ of water) was prepared two hours before connection to the trap because the $\mathrm{CO}_{2}$ output rate takes 1.5 hour to stabilize [58]. The $2 \mathrm{l}$ bottle with the solution was connected with a polypropylene tube to a smaller bottle $(0.5 \mathrm{l})$ holding the overflowed solution. The small bottle was then connected to the trap. A 6-volt motor powered by rechargeable batteries drove a fan and diodes. The set-up was covered by a plate of $30 \mathrm{~cm}$ and helped attract mosquitoes into a net.

Traps were placed in three different sites to compare features of two types of sites used by chimpanzees (feeding and nesting sites) with control sites during four consecutive days every week: (i) feeding sites used by chimpanzees after 16:30, (ii) nesting sites, (iii) control sites independent of chimpanzee travel (village, hill, swamps). At nesting sites, traps were suspended either at a height of $2 \mathrm{~m}$ above ground or at the height of one of the nest (up to an height of $17 \mathrm{~m}$ ) and in a close vicinity of the ape (i.e. within a $5 \mathrm{~m}$ perimeter centred on the tree used by the chimpanzee) (Table 1). Traps were switched on late afternoon or evening (16:3019:00) according to feeding and nesting time of the chimpanzees, and switched off and retrieved in the morning (06:30-07:30). A total number of 300 traps were placed in Kanyawara and 83 in Kanyanchu.

Altitude (GPS Garmin map 60") of the trapping sites were recorded as well as the temperature and relative humidity, i.e. hygrometry (Oregon Scientific EMR $812^{\circledR}$ ), once when the traps were switched on and again when they were switched off (i.e. evening and morning for each trapping site). After trap retrieval, the net was removed then sealed and placed in a big plastic bag (30 l) where insects were anesthetized with chloroform. At the research station, mosquitoes were sorted out from other insects and a score ranging from 0 to 3 was determined according to their abundance $(1=1-10 ; 2=11-20 ; 3>20)$. Anopheles females were then identified by visual examination, individually counted and then dissected.

Abdomens were stored in 95\% ethanol. The head, wings and thorax of each specimen were kept in a dry tube with silica gel to be used for species identification according to identification keys of Gillies and De Meillon [60]. Mosquito collections were carried out regularly throughout the twoyear period. Data from traps placed during four consecutive days per week were used to assess the influence of collection conditions (Table 1), on the mosquitoes caught.

\section{Sampling and detection of Plasmodium from humans and mosquitoes}

Finger-prick blood drops were collected into EDTA tubes, during routine medical diagnosis and treatment by the

Table 1 Protocol followed for Anopheles collection in the Kanyawara and Kanyanchu sites, Kibale NP, Uganda

\begin{tabular}{|c|c|c|c|c|c|c|}
\hline \multirow[b]{2}{*}{ Day } & \multicolumn{3}{|c|}{ Trap 1} & \multicolumn{3}{|c|}{ Trap 2} \\
\hline & $\mathrm{CO}_{2}$ & Site & Trap height & $\mathrm{CO}_{2}$ & Site & $\overline{\text { Trap height }}$ \\
\hline 1 & no & Chimpanzees feeding site & $2 \mathrm{~m}$ & no & Chimpanzees nesting site & $2 \mathrm{~m}$ \\
\hline 2 & no & Chimpanzees nesting site & $2 \mathrm{~m}$ & no & Chimpanzees nesting site & Nest height \\
\hline 3 & yes & Chimpanzees nesting site & $2 m$ & yes & Chimpanzees nesting site & $\overline{\text { Nest height }}$ \\
\hline 4 & no & village & $2 m$ & yes & village & $2 m$ \\
\hline
\end{tabular}


nurses of Mpanga Tea Factory Dispensary, from 74 informed people (villagers, workers and field assistants) who gave their consent in writing for the study. Formal approval was sought from local and national ethical committees but this was not deemed necessary because the samples were only destined for Plasmodium detection. All of persons sampled were at the time working in the Kibale $\mathrm{NP}$, or within less than $1 \mathrm{~km}$ of the forest border, none were living at more than $15 \mathrm{~km}$ away from the forest. Of the people sampled, 78\% lived less than $2 \mathrm{~km}$ from the forest and $28 \%$ declared they live less than $500 \mathrm{~m}$ from a swamp. The blood samples were also tested at the time of collection with a Rapid Detection Test (Core DiagnosticTM), and persons found positive were informed of the result and treated appropriately by the medical staff of the Dispensary.

DNA was extracted from finger-prick blood samples and from 100 mosquito carcasses that were kept dry or in ethanol, using the DNeasy Blood \& Tissue Kit Qiagen kit (Qiagen, Germany). Six mosquitoes where the species could not be determined were processed individually for DNA extraction, as were 11 Anopheles demeilloni, four Anopheles implexus, and two Anopheles vinckei. For the remaining 77 mosquitoes (10 A. demeilloni, $48 \mathrm{~A}$. implexus, and $19 A$. vinckei), three to six (usually five) carcasses were pooled before DNA extraction. In all cases, a final volume of $100 \mu \mathrm{l}$ of DNA template was obtained.

Two different sensitive nested PCR protocols were applied to these templates; the first was based on the parasite's small subunit ribosomal RNA (ssrRNA), and the second on its mitochondrial DNA. For all samples, $5 \mu$ of template DNA were used to initiate the primary reactions, and $1 \mu \mathrm{l}$ from the resulting product was used to initiate the secondary reactions. For the ssrRNAbased detection, genus-specific oligonucleotide primers were used, rPLU1 + rPLU2 in the primary amplification and rPLU3 + rPLU4 in the secondary amplification, and for the positive samples a second round of secondary reactions was conducted to identify the species present, as described in a previously published protocol [61]. For the mitochondrial genome-based detection the primary reaction was carried out using MI-OF4A 5'GATGGAAACAGCCGGAAAG and MI-NR4 5'- ATA CAGTCCCAGCGACAGC, and the secondary reaction with GS-F4A 5'- ATTAAAGGAACTCGACTGGCC and MI-NR4. The enzyme used was Phusion High Fidelity Taq polymerase (New England Biolabs, USA) and the reaction conducted in the buffer provided at final concentrations of $3 \mathrm{mM}$ for $\mathrm{Mg} 2+$ and $125 \mathrm{nM}$ for each oligonucleotide primer. Following an initial denaturation of $5 \mathrm{~min}$ at $95^{\circ} \mathrm{C}$, 30 cycles at $50^{\circ} \mathrm{C} 15 \mathrm{sec}, 72^{\circ} \mathrm{C} 15 \mathrm{sec}$ and $98^{\circ} \mathrm{C} 10 \mathrm{sec}$ were carried out for the first reaction and 35 cycles at $65^{\circ} \mathrm{C}$ $15 \mathrm{sec}, 72^{\circ} \mathrm{C} 15 \mathrm{sec}$ and $98^{\circ} \mathrm{C} 10 \mathrm{sec}$ for the second reaction. In the final cycle the extension was carried out for $5 \mathrm{~min}$ before bringing the reaction to room temperature.
The products were visualized by ethidium bromide staining after electrophoresis on a 3\% agarose gel.

\section{Statistical analysis}

Wilcoxon tests were used for paired samples when results of the same day were compared according to $\mathrm{CO}_{2}$ use, trap height, feeding site versus nesting site. To compare medians of the samples, Mann-Whitney for independent samples were used since normality tests were usually not passed (two-tailed P value). Non-parametric correlations between variables were measured with Spearman $\mathrm{r}$ (two-tailed P value).

\section{Results}

Potential vectors of Plasmodium species of chimpanzees In Kanyawara, a total of 245 female Anopheles were collected in 113 traps over 151 nights of trapping (72 during the dry season and 79 during the rainy season), and in Kanyanchu 64 female Anopheles were caught in 36 traps over 43 nights of trapping. The highest number of female Anopheles found in a single trap was 28 in Kanyawara and 10 in Kanyanchu, and that of specimens caught on any one day (22 March 2007) was 34 in Kanyawara and 13 in Kanyanchu (29 May 2009), and these belonged to four species. In Kanyawara, a total 10 species of Anopheles were caught, and nine could be identified, while only three species were collected in Kanyanchu. Four of the species belonged to the sub-genus Anopheles and five to the sub-genus Cellia (51\% of Anopheles vs $49 \%$ Cellia). Five of the nine known series (Myzorhynchus, Christya, Neomyzomya, Myzomya, Cellia) are represented (Table 2).

The three species most frequently collected were A. implexus (Kanyawara: 120/245, 49\%; Kanyanchu: 42/64, 66\%), A. vinckei (Kanyawara: 58/245, 24\%; Kanyanchu: 15/ 64, 23\%), and $A$. demeilloni (Kanyawara: 53/245, 22\%; Kanyanchu: 6/64, 9\%) (Figure 1). In Kanyawara, $A$ implexus were collected throughout the two years (21/24 months), while $A$. demeilloni and $A$. vinckei were only collected

\begin{tabular}{|c|c|c|c|}
\hline \multicolumn{4}{|l|}{ Genus Anopheles } \\
\hline Sub-genus Anopheles & & Sub-genus Cellia & \\
\hline Christya & A. implexus & Myzomya & A. demeilloni \\
\hline \multirow[t]{3}{*}{ Myzorhynchus } & A. paludis & & A. harperi \\
\hline & A. ziemanni & & A. marshallii \\
\hline & A. obscurus & Neomyzomya & A. vinckei \\
\hline \multirow[t]{4}{*}{ Anopheles } & & Cellia & A. squamosus \\
\hline & & Neocellia & \\
\hline & & Pyretophorus & \\
\hline & & Paramyzomya & \\
\hline
\end{tabular}




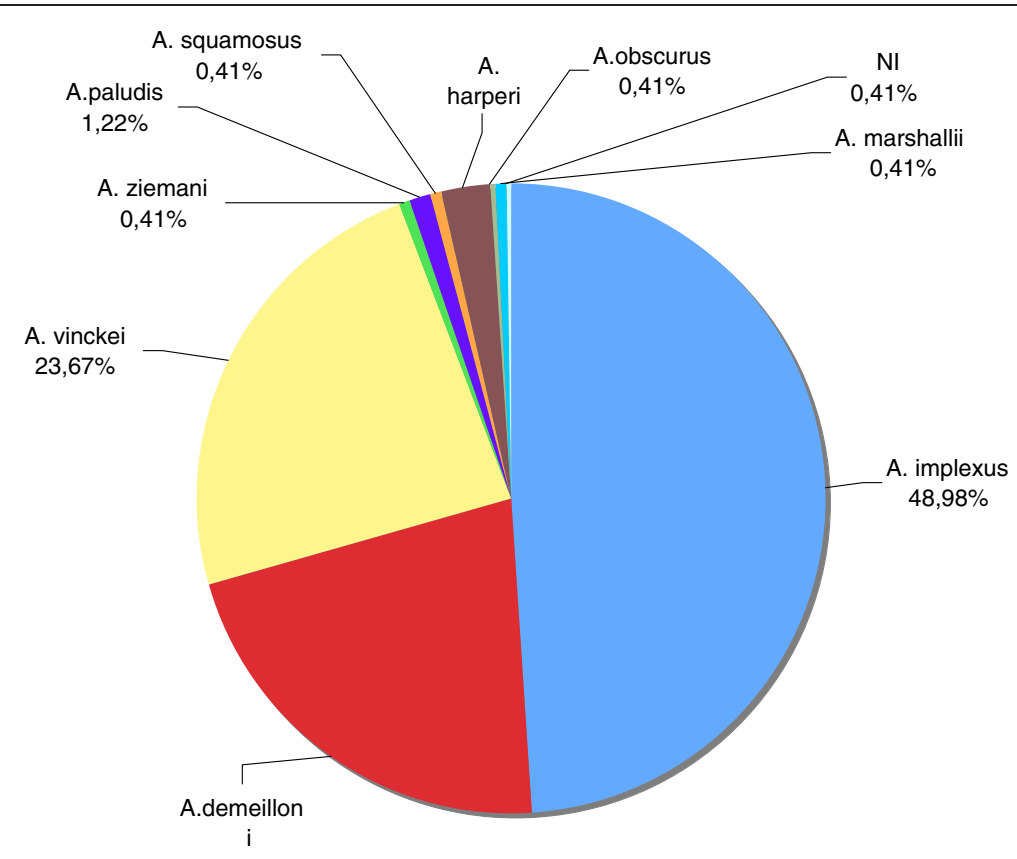

Figure 1 Proportion of the Anopheles species identified in Kanyawara (2006-2008).

during 13 and 12 months of the study, respectively. The month when collections were most abundant (47 individuals) was August 2007, and up to five species were collected in July, October and December 2006.

\section{Factors that influenced the presence of Anopheles in the home range of chimpanzees}

Anopheles females were caught in 72 out of the 300 traps placed in Kanyawara and in 30 of the 83 traps in Kanyanchu. These anophelines were further analysed with respect to the following factors:

\section{Meteorological factors}

The temperature was significantly higher and the hygrometry lower in Kanyanchu ( $\mathrm{n}=36$ nights) compared to the dry season of collection in Kanyawara ( $n=70$ nights) (morning temperature: Kanyawara: $16^{\circ} \mathrm{C}$ Kanyanchu: $18.3^{\circ}$ $\mathrm{C}$ Mann-Whitney Test $\mathrm{P}<0.005$; evening temperature: Kanyawara: $20^{\circ} \mathrm{C}$ Kanyanchu: $22.1^{\circ} \mathrm{C}$ Mann-Whitney Test $\mathrm{P}<0.001$; morning hygrometry: Kanyawara: $89 \%$ Kanyanchu: 81\% Mann-Whitney Test $\mathrm{P}=0.078$; evening hygrometry : Kanyawara: $82.7 \%$ Kanyanchu : $75.5 \%$ Mann-Whitney Test $\mathrm{P}=0.011$ ). Humidity was found to affect trapping success. In Kanyawara, hygrometry was significantly higher for traps in which females Anopheles were caught than for those found empty in the evening (Kanyawara: $78 \%$ empty traps vs $83 \%$ traps with Anopheles, Mann-Whitney test, $\mathrm{P}=0.0009$;), or in the morning (Kanyawara: 85\% empty traps vs 90\% traps with Anopheles, Mann-Whitney test $\mathrm{P}<0.0001$;). In
Kanyanchu, no significant relation was found but the hygrometry was lower compared to Kanyawara (Kanyanchu: evening $76.9 \%$ empty traps vs $73.1 \%$ traps with Anopheles Mann-Whitney Test $\mathrm{P}=0.28$; morning: $80.7 \%$ empty traps vs $81.3 \%$ traps with Anopheles, Mann-Whitney Test $\mathrm{P}=0.97$ ). For both empty traps and those with Anopheles, the temperatures recorded did not differ significantly (Kanyawara: evening catches $20.4^{\circ} \mathrm{C}$ for empty traps $v s$ $20.2^{\circ} \mathrm{C}$ for traps with Anopheles, Mann-Whitney test $\mathrm{P}=0.35$; Kanyanchu: empty $21.9^{\circ} \mathrm{C}$ with Anopheles $22.1^{\circ} \mathrm{C}$, Mann-Whitney Test $\mathrm{P}=0.287$; Kanyawara: morning catches $16.1^{\circ} \mathrm{C}$ for empty traps $v s 16.1^{\circ} \mathrm{C}$ for traps with Anopheles, Mann-Whitney test $\mathrm{P}=0.38$, Kanyanchu empty $18.8^{\circ} \mathrm{C}$; with Anopheles $18.0^{\circ} \mathrm{C}$, Mann-Whitney Test $\mathrm{P}=0.96)$.

\section{Ecological factors}

Mosquitoes, and female Anopheles in particular, were significantly more abundant in traps placed in the forest compared to those located in the villages, both in Kanyawara and Kanyanchu (mosquito scores for Kanyawara: forest $=1.56$, village $=0.85$, Mann-Whitney Test $\mathrm{P}$ $<0.0001$; number of female Anopheles per trap: forest = 0.66 , village $=0.10$, Mann - Whitney Test $\mathrm{P}=0.0092$; for Kanyanchu mosquito score: forest $=1.11$; village $=0.4$ Mann-Whitney Test P =0.0024; number of female Anopheles/trap: forest $=1.23$; village $=0.06$, Mann-Whitney Test $\mathrm{P}=0.000097)$. Anopheles implexus and Anopheles marshalli were the only species collected in the villages. 


\section{Trap type}

Trapping-methods did not significantly affect trapping success. $\mathrm{CO}_{2}$ as compared to non- $\mathrm{CO}_{2}$ traps tended to attract more mosquitoes in general and female Anopheles in particular, but the difference was not significant in either communities. Anopheles implexus were slightly more attracted by the presence of $\mathrm{CO}_{2}$ than $A$. vinckei and A. demeilloni (Figure 2).

\section{Variation in vector distribution between chimpanzee feeding and nesting sites Topographical factors}

The mean altitude of the chimpanzee feeding sites, nesting sites and villages, where traps were set, was significantly higher for Kanyawara compared to that of Kanyanchu (unpaired $t$ test: Kanyawara: $1,506 \mathrm{~m}, \mathrm{n}=106$; Kanyanchu: $1,260 \mathrm{~m}, \mathrm{n}=38, \mathrm{P}<0.0001)$. The mean altitude of the chimpanzee feeding sites was lower than that of their nesting sites (feeding site $=1506 \mathrm{~m} v s$ nesting site $=1516 \mathrm{~m}$, Wilcoxon test for 28 pairs of days 1, eight pairs excluded because equal, $\mathrm{P}=0.04, \mathrm{r}$ Spearman $=0.53, \mathrm{P}=0.0004$ ). The mean altitude of traps containing female Anopheles was lower (Kanyawara: 1,502 m, $n=65$; Kanyanchu $1,257 \mathrm{~m}, \mathrm{n}=28$ ) than that of empty traps (Kanyawara: 1,512 m, n= 246; Kanyanchu 1,269 m, n=53), however, the difference between the medians was not significant (respectively Mann-Whitney Test $\mathrm{P}=0.1$ and 0.22 ).

\section{Positional factors}

The nest height was not significantly different between two sites during the study periods (Kanyawara $9.1 \mathrm{~m}$, $\mathrm{n}=74$; Kanyanchu $8.1 \mathrm{~m}, \mathrm{n}=30$; unpaired $t$ test $\mathrm{P}=0.12$ ). In Kanyawara, the number of chimpanzee nests in a

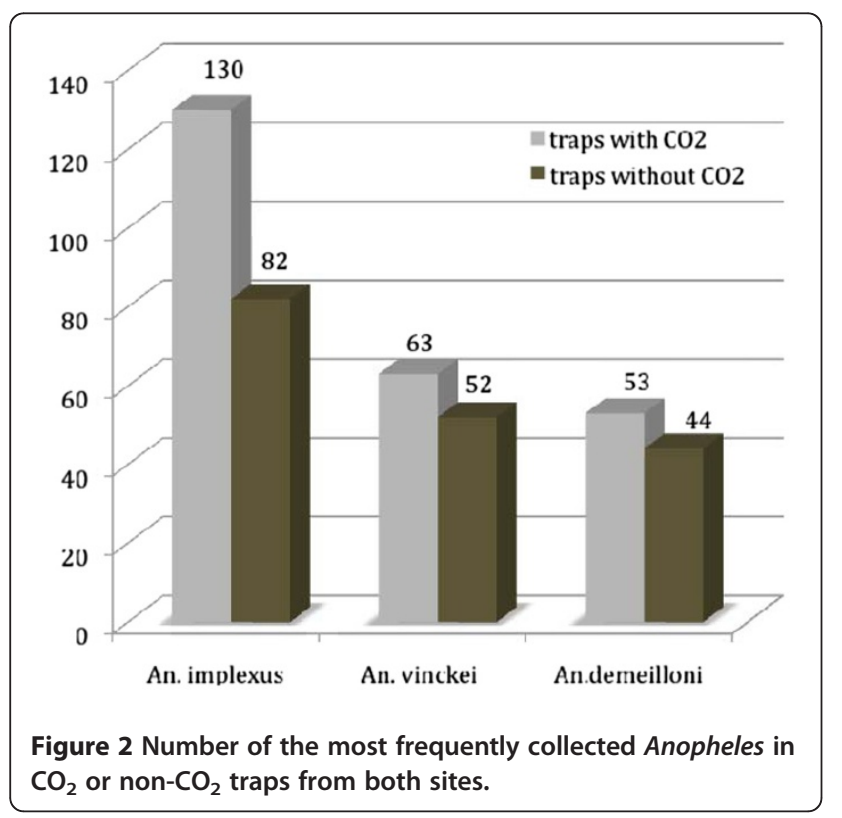

nesting site was negatively correlated with mosquito abundance $(\mathrm{r}=-0.18 ; \mathrm{P}=0.01)$.

Considering the two sites together, mosquito scores and trap height were negatively correlated $(\mathrm{r}=-0.24, \mathrm{P}<0.0001$, $\mathrm{n}=416$ ). Species composition varied with trap height and thus, nest height. Only two species were present, with A. implexus dominating (83\% in Kanyawara; 58\% in Kanyan$\mathrm{chu}$ ) in traps placed close to the chimpanzees and at their nest heights (between 3 to $17 \mathrm{~m}$ above ground). By contrast, in traps placed at $2 \mathrm{~m}, 10$ species were present and $A$. implexus represented only $38 \%$ of the specimens in Kanyawara, though $77 \%$ in Kanyanchu (Figure 3).

\section{Molecular detection of Plasmodium parasites in humans and mosquitoes}

Plasmodium parasites could not be detected in either duplicate amplification reactions of any of the DNA template purified from the female Anopheles samples collected, either when using the primers targeting the ssrRNA or those targeting the mitochondrial DNA. On the other hand, many of the blood samples $(60 \%)$ collected from the humans working in or within $1 \mathrm{~km}$ of the forest where the chimpanzee communities were found to harbour malaria parasites. Of the 74 human blood samples collected, 44 were found positive for Plasmodium parasites. P. falciparum was found in $80 \%$ of the positive samples and as a mixed infections in another $16 \%$. The parasite species present were $P$. falciparum only in 30 samples, $P$. falciparum $+P$. ovale in five, $P$. falciparum $+P$. malariae in one, and $P$. ovale only in a single sample. The species could not be determined in the seven remaining samples, most likely because the amount of DNA was limiting.

\section{Discussion}

Over a period of 28 months, 309 female Anopheles, from 10 species, were collected in 383 traps placed in the habitat of two chimpanzee communities (Kanyawara and Kanyanchu) in Western Uganda. The number of species caught was consistent with other studies conducted in tropical areas: 10 species were collected in Malaysia in eight nights [62]. The number of anopheline mosquitoes caught might be considered to be quite low as compared to the numbers obtained in some studies conducted in human and livestock environments. For example, in a 1.5 -year study conducted with light traps in Kenya, about 15,000 and 60,000 female Anopheles from only four species were collected inside and outside houses, respectively [63]. On the other hand, when the mosquito surveys were conducted in an environment similar to that where the chimpanzees live, namely cool highlands, the number of Anopheles collected is often very low: for instance using the same methodology and sampling protocols, 107 Anopheles were collected at Kyenjojo (about $20 \mathrm{~km}$ to 


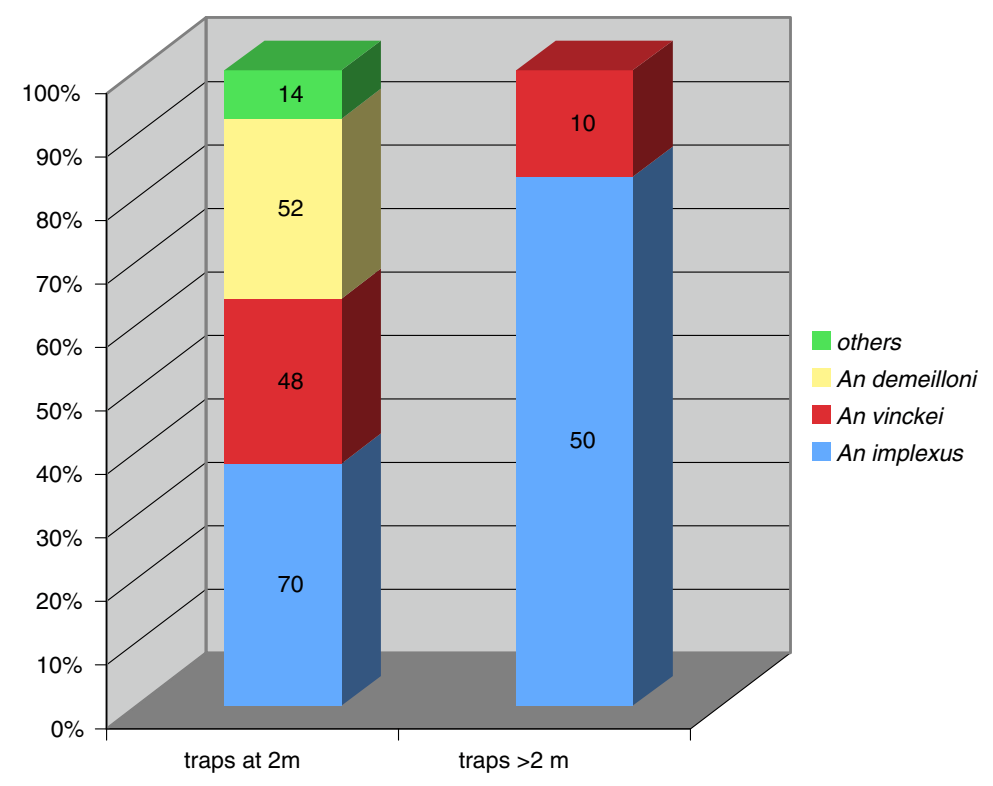

Figure 3 Species and number of Anopheles females captured. Traps were placed either at $2 \mathrm{~m}$ above the ground and close to a chimpanzee during the night, or at the height of its nest.

Kibale NP) as compared to the 10,127 Anopheles collected in Tororo, a dry savannah grassland area [64].

Ultimately the ecology and host preference of the Anopheles species identified in the home range of chimpanzees remain poorly documented. However, the meager observations do not exclude a role in malaria transmission. Only one of these species, Anopheles paludis, has been incriminated as an important vector of human malaria [65], though this role appeared to vary with geographical location. The forest species A. implexus has been described as an anthropophilic taxon, and in 1960, Lips found one female infected with malaria out of 1,200 dissected. Breeding places were usually described to be swamps, stagnant shady drains, water containing dead leaves and elephant tracks [66], but Lambrecht [67] failed to find any larva or egg in the forest gallery where adults where collected despite repeated efforts. Anopheles obscurus, commonly found in forests, does not bite humans but was found carrying malaria oocysts $[68,69]$. Anopheles squamosus, abundant from the peak to the end of the rainy season [70], is close to Anopheles pharaoensis but its role in human malaria transmission does not seem to be major. Anopheles ziemani is mostly described as a zoophilic species but has nevertheless been implicated in human malaria transmission [71]. Anopheles demeilloni lives in altitude (700 to1,800 m), as does Anopheles harperi a rather zoophilic and exophilic species. Anopheles vinckei is poorly described and its distribution is limited to Oriental Kivu in Democratic Republic of Congo and Western Uganda.

Three Anopheles species (A. implexus, A. vinckei and $A$. demeilloni) represented more than $94 \%$ of the catch but only one, A. implexus, was dominant in the vicinity of the chimpanzees' nests where it was consistently captured (21 months over 24 of study). In a previous study [12], blood samples were obtained serendipitously from three Kanyawara community chimpanzees: one was injured in the course of a fight in September 2006, one as it was released from a poacher's snare in October 2006, and the third in the course of a post-mortem in January 2007. Molecular analysis of the genomic DNA prepared from these samples revealed that all these three chimpanzees sampled randomly, within the study-period of the present survey, were infected with multiple species of Plasmodium [12]. Given that the Kanyawara community comprises only 44 individual chimpanzees, the presence of infections in three strongly suggests a very high prevalence of malaria in these apes, and this can only be due to high transmission rates, chronic persistence of parasites over long durations, or both. Observations of mixed infections in wild-caught chimpanzees are common as are sub-patent infections that persist for many years $[15,16]$. The prevalence of infection was high in the human blood samples analyzed, with Plasmodium parasites detected using the same PCR assays in 44 of the 74 (60\%) persons sampled.

Plasmodium parasites could not be detected by PCR amplification in any of the Anopheles mosquitoes caught. Given the very low numbers of mosquitoes that were actually caught in the vicinity of the chimpanzee nests, this was to be expected since the infection rates observed in mosquitoes are usually low $(<1 \%)$ as are the parasite burdens (an average of one oocyst) even in mosquitoes caught in areas of high malaria 
endemicity. Ideally, one can optimize the chances to uncover the mosquitoes that transmit the parasite by collecting specimens that have fed on the chimpanzees, but this is impossible to achieve for individuals in the wild. One can also minimize the possibility of degradation by processing the mosquito material for DNA extraction immediately after collection. In this manner, it will be possible to target studies of chimpanzee behaviour in relation to mosquito avoidance. However, such studies are technically and practically challenging to conduct.

The hypothesis tested in this study was that Anopheles abundance would be higher in areas of the chimpanzees' home range that have lower altitude and are more humid. Furthermore, if diseases transmitted by anophelines were to impact on chimpanzee health, then the apes would be more likely to select nesting sites away from the wetter areas and at levels with the lowest Anopheles abundance. Although the data presented here could be interpreted to support this hypothesis, the numbers of mosquitoes caught were low. Several recent studies emphasized the strong and synergistic effects of microclimate and altitude on malaria risk in human population, especially in highland sites $[35,53,72]$. In such areas, the valleys and basin-like depressions were recognized as less desirable areas to live, people living in the valleys receive more infective bites under such ambient conditions and the human density in these foci was relatively lower [35]. In the present study, the number of Anopheles females caught varied with the altitude, temperature and hygrometry of the various sites where the traps were placed and the same patterns of choice for sleeping sites are observed in chimpanzees. Differences related to captures in the two close sites sampled (separated by less than $20 \mathrm{~km}$ but characterized by different microclimates) are not surprising. Ernst et al. [53] conducted a study in a $16 \mathrm{~km}^{2}$ area where elevation ranged from 1,829 to $2,132 \mathrm{~m}$ and showed striking magnitude of the differences even within this small area (up to 39-fold differences in incidence between the sub-unit areas of highest and lowest incidence). In our survey, the study in Kanyawara, the site of highest altitude, wetter atmosphere and cooler temperature, monitored during both rainy and dry seasons underlined the effects of climatic and spatial factors on the trap yields.

The low abundance of adult mosquitoes caught in the chimpanzees' night environment might be in part explained by aspects of chimpanzee behaviour that lead to a reduction of exposure to malaria vectors. Chimpanzees are mobile and every evening they build a night nest in a new location within a large home range, about $20 \mathrm{~km}^{2}$ in the present study-sites. In addition, even if chimpanzees are social, their population density is low (2.4 individuals/ $\mathrm{km}^{2}$ ) and their system of fission-fusion prevents a high concentration of chimpanzees in a same nesting site at a same time. In Kibale NP, wet areas are usually found in the valley where swamps are frequent and footprints of elephants are very abundant. In human communities within a small area of $16 \mathrm{~km}^{2}$, proximity to forest and swamp have both been associated with significant increased vector density: vector density has been shown to cluster in low-lying swampy areas [53]. The present results indicated that chimpanzees build nests at a higher altitude than the sites where they feed, suggesting that they prefer nesting site above the wet valley. A topographic preference of chimpanzees for nesting on ridges and shoulders was also noted by Furuichi and Hashimoto [73]. The negative correlation observed between nest number and mosquito abundance is consistent with these findings, although it cannot be exclude that mosquitoes might be more attracted by chimpanzees than by the traps. Nonetheless, the higher the nest site, the less diverse were the species of Anopheles encountered. There are many factors, such as predation pressure, body size or comfort, that have been proposed to influence the construction and selection of sleeping shelters and their height by great apes [74,75]. It was even suggested that nest construction could explain the cognitive evolution of hominoids through long-term memory consolidation related to higher quality sleep [76]. The present survey suggests that mosquito avoidance should be also considered as a factor in the selection of the nest location and height. This is especially relevant in Kibale NP where no predators exist and where chimpanzees are not hunted. Provided that the negative correlation between nest number/height and mosquito abundance does not reflect a higher attraction of mosquitoes to chimpanzees than to the traps, it would appear that chimpanzees select a nesting site where relatively few biting mosquitoes occurred. Moreover, mosquitoes are vectors of other diseases, including arboviral infections, that affect great apes and thus that can have significant impact on mortality and morbidity of wild primate populations [77].

From a conservation point of view, it would be of great importance to collect mosquitoes in the different sites where chimpanzees live. This is of particular importance with respect to degraded forest and at the edge of the park sites, where the vector species and their infections might differ from those collected in the middle of the park. Data records extending back to 1903 indicate that the Kibale region has become moister [78], which would likely lead to an increase in mosquito abundance. It is possible that chimpanzees, which had been adapted over thousands of years to forest vectors and parasites, might face novel threats to their health as changing climate and land conversion force then to live in fragmented forests and to use more frequently the forest edge. 


\section{Conclusions}

Ten anopheline species were collected in the home range of chimpanzees living in Ugandan highlands. This number is comparable to that recorded in the course of other studies conducted in tropical areas of similar ecological characteristics. The endemicity of Plasmodium infection is likely to be as high in chimpanzees as it is in humans living in this area. Nonetheless, none of the 100 female Anopheles analysed were positive for Plasmodium. This is not unexpected because the total number of female Anopheles that was collected in the home range of the chimpanzees was low, and the infection rates normally observed in wild-caught Anopheles are usually low (less than 1\%). The dominant species in the vicinity of chimpanzee nests was A. implexus, which makes it the most likely species to serve as a vector for the Plasmodium species of chimpanzees. Further sampling will be required to confirm or refute this. Chimpanzee nesting sites were located in higher and drier locations where the female Anopheles caught were less abundant than in the sites where the chimpanzees were feeding. Furthermore, the number of chimpanzee nests at a nesting site was negatively correlated with the mosquito abundance. The site that the chimpanzees choose for nesting every night might be selected in part so as to minimize contact with anopheline mosquitoes, and this in turn might lead to a reduced risk in acquiring a malaria infection.

\section{Competing interests}

The authors declare that they have no competing interests.

\begin{abstract}
Authors' contributions
SK conceived of the study, participated in the data collection, performed the Anopheles identification and the statistical analysis and drafted the manuscript. J-MK and FL participated in the data collection. MC participated in the data collection and in editing the manuscript. ST and MI carried out the molecular genetic studies. GS, ST and MI designed and carried out the molecular assays, GS also contributed to the editing of the manuscript. JMK participated in the design of the study. JCG participated in the design of the study, performed the Anopheles identification and contributed to the editing of manuscript. All authors read and approved the final manuscript.
\end{abstract}

\begin{abstract}
Acknowledgements
We are very grateful to the Uganda Wildlife Authority, the Uganda National Council for Science and Technology for permission to conduct this research and R. Wrangham, Kibale Chimpanzee Project, Makerere University Biological Field Station and the Mpanga Tea Factory Dispensary and its staff for logistic support. Financial support was obtained from the Muséum National d'Histoire Naturelle, Fyssen Fondation and ANR SAFAPE for Sabrina Krief and from National Geographic Society for Florence Levrero. We deeply thank Mathilde Pouget who initiated the Anopheles collection, Alexandre Tanneau, Ronald Musinguzi and Japan Musinguzi for their assistance during fieldwork. We are very grateful to the two anonymous reviewers who provide useful comments to a previous version of this manuscript for its improvement.
\end{abstract}

\section{Author details}

'UMR 7206- Eco-anthropologie et ethnobiologie, Muséum National d'Histoire Naturelle, Paris, France. ${ }^{2}$ Projet pour la Conservation des Grands Singes, Paris, France. ${ }^{3}$ Université de Saint-Etienne, Equipe de Neuro-Ethologie Sensorielle/ CNPS, CNRS UMR 8195. Centre National de la Recherche Scientifique, Centre de Neurosciences Paris-Sud, UMR 8195, Saint Etienne, France. ${ }^{4}$ Faculty of
Tropical Medicine, Mahidol University, Bangkok, Thailand. ${ }^{5}$ Institut National de la Santé et de la Recherche Médicale, Unité Mixte de Recherche, S 945 Paris, France. 6 Université Pierre \& Marie Curie, Faculté de Médecine PitiéSalpêtrière, Paris, France. ${ }^{7}$ Makerere University Biological Field Station, Fort Portal, Uganda. ${ }^{8}$ Faculté de Pharmacie de Châtenay-Malabry, Paris, France.

Received: 13 January 2012 Accepted: 6 April 2012

Published: 17 April 2012

\section{References}

1. Boesch C: Why do chimpanzees die in the forest? The challenges of understanding and controlling for wild ape health. Am J Primatol 2008, 70:722-726.

2. Ferber D: Human diseases threaten great apes. Science 2000, 289:1277-1278.

3. Leendertz FH, Junglen $\mathrm{S}$, Boesch C, Formenty P, Couacy-Hymann E, Courgnaud V, Pauli G, Ellerbrok E: High variety of different simian T-Cell leukemia virus type 1 strains in chimpanzees (Pan troglodytes verus) of the Taii National Park, Côte d'Ivoire. J Virol 2004, 78:4352-4356.

4. Leendertz FH, Pauli G, Maetz-Rensing K, Boardman W, Nunn C, Ellerbrok H, Jensen SA, Junglen S, Boesch C: Pathogens as drivers of population declines: The importance of systematic monitoring in great apes and other threatened mammals. Biol Conserv 2006, 131:325-337.

5. Leendertz FH, Yumlu S, Pauli G, Boesch C, Couacy-Hymann E, Vigilant L, Junglen S, Schenk S, Ellerbrok H: A new Bacillus anthracis kills wild chimpanzees and gorilla in West and Central Africa. PLoS Pathog 2006, 2:e8

6. Goldberg TL, Gillespie TR, Rwego IB, Wheeler E, Estoff EL, Chapman CA: Patterns of gastrointestinal bacterial exchange between chimpanzees and humans involved in research and tourism in western Uganda. Biol Conserv 2007, 135:511-517.

7. Krief S, Jamart A, Mahé S, Leendertz FH, Mätz-Rensing K, Crespeau F, Bain O, Guillot J: Clinical and pathological manifestation of oesophagostomosis in African great apes. Does self-medication in wild apes influence disease progression? J Med Primatol 2008, 37:188-195.

8. Levréro F, Gatti S, Gautier-Hion A, Ménard N: Yaws disease in a wild gorilla population and its impact on the reproductive status of males. Am J Phys Anthropol 2007, 132:568-575.

9. Caillaud D, Levréro F, Cristescu R, Gatti S, Dewas M, Douadi M, Gautier-Hion A, Raymond M, Ménard M: Gorilla susceptibility to Ebola virus: The cost of sociality. Curr Biol 2006, 16:489-491.

10. Köndgen $S$, Kühl H, N'Goran PK, Walsh PD, Schenk S, Ernst N, Biek R, Formenty P, Matz-Rensing K, Schweiger B, Junglen S, Ellerbrok H, Nitsche A, Briese T, Lipkin WI, Pauli G, Boesch C, Leendertz FH: Pandemic human viruses cause decline of endangered great apes. Curr Biol 2008, 18:260-264.

11. Kaur T, Singh J, Tong S, Humphrey C, Clevender D, Tan W, Szekely B, Wang Y, Li Y, Muse EA, Kiyono M, Hanamura S, Inoue E, Nakamura M, Huffman MA, Jiang B, Nishida T: Descriptive epidemiology of fatal respiratory outbreaks and detection of a human-related metapneumovirus in wild chimpanzees (Pan troglodytes) at Mahale Mountains National Park, Western Tanzania. Am J Primatol 2008, 70:755-765.

12. Krief S, Escalante AA, Pacheco MA, Mugisha L, André C, Halbwax M, Fischer A, Krief JM, Kasenene JM, Crandfield M, Cornejo OE, Chavatte JM, Lin C, Letourneur F, Grüner AC, McCutchan TF, Rénia L, Snounou G: On the diversity of malaria parasites in African apes and the origin of Plasmodium falciparum from bonobos. PLoS Pathog 2010, 6:e1000765.

13. Krief S, Vermeulen B, Lafosse S, Kasenene JM, Nieguitsila A, Berthelemy M, L'Hostis M, Bain O, Guillot J: Nodular worm infection in wild chimpanzees in Western Uganda: A risk for human health? PLOS Negl Trop Dis 2010, 4:e630

14. WHO : Malaria factsheet [http://who.int/mediacentre/factsheets/fs094/en/ print.html]

15. Garnham PPC: Malaria parasites and other haemosporidiae. Oxford: Blaskwell Scientific Publications; 1966.

16. Coatney GR, Collins WE, Warren M, Contacos PG: The Primate Malarias. Washington DC: GPO; 1971

17. Ollomo B, Durand P, Prugnolle F, Douzery E, Arnathau C, Nkoghe D, Leroy E, Renaud F: A new malaria agent in African Hominids. PLoS Pathog 2009, 5: e1000446

18. Prugnolle F, Durand P, Neel C, Ollomo B, Ayala FJ, Arnathau C, Etienne L, Mpoudi-Ngole E, Nkoghe D, Leroy E, Delaporte E, Peeters M, Renaud F: African great apes are natural hosts of multiple related malaria species, including Plasmodium falciparum. Proc Natl Acad Sci USA 2010, 107:1458-1463. 
19. Duval L, Fourment M, Nerrienet E, Rousset D, Sadeuh SA, Goodman SM, Andriaholinirin NV, Randrianarivelojosia M, Paul RE, Robert V, Ayala FJ, Ariey F: African apes as reservoirs of Plasmodium falciparum and the origin and diversification of the Laverania subgenus. Proc Natl Acad Sci USA 2010, 107:10561-10566.

20. Liu W, Li Y, Learn GH, Rudicell RS, Robertson JD, Keele BF, Ndjango JBN, Sanz CM, Morgan DB, Locatelli S, Gonder MK, Kranzusch PJ, Walsh PD, Delaporte E, Mpoudi-Ngole E, Georgiev AV, Muller MN, Shaw GM, Peeters M, Sharp PM, Rayner JC, Hahn BH: Origin of the human malaria parasite Plasmodium falciparum in gorillas. Nature 2010, 467:420-425.

21. Kaiser M, Löwa A, Ulrich M, Ellerbrok H, Goffe AS, Blasse A, Zommers Z, Couacy-Hymann E, Babweteera F, Zuberbühler K, Metzger S, Geidel S, Boesch C, Gillespie TR, Leendertz FH: Wild chimpanzees infected with 5 Plasmodium species. Emerg Infect Dis 2010, 16:1956-1959.

22. Duval L, Nerrienet E, Rousset D, Sadeuh Mba SA, Houze S, Fourment M, Le Bras J, Robert V, Ariey F: Chimpanzee malaria parasites related to Plasmodium ovale in Africa. PLOS ONE 2009, 4:5520

23. Hayakawa T, Arisue N, Udono T, Hirai H, Sattabongkot J, Toyama T, Tsuboi T, Horii T, Tanabe K: Identification of Plasmodium malariae, a human malaria parasite, in imported chimpanzees. PLOS ONE 2009, 4:e7412.

24. Kilian AHD, Langi P, Talisuna A, Kabagambe G: Rainfall pattern, El Niño and malaria in Uganda. Trans R Soc Trop Med H 1999, 93:22-23.

25. Lepers JP, Deloron P, Fontenille D, Coulanges P: Reappearance of falciparum malaria in central highland plateaux of Madagascar. Lancet 1988, 331:586

26. Marimbu J, Ndayiragije A, Le Bras M, Chaperon J: Environnement et paludisme au Burundi: à propos d'une épidémie de paludisme dans une région montagneuse non endémique. Bull Soc Pathol Exot 1993, 86:399-401.

27. Some ES: Effects and control of a highland malaria epidemic in Uasin Gishu District, Kenya. E Afr Med J 1994, 71:2-8

28. Kigotho AW: Services stretched as malaria reaches Kenyan highlands. Lancet 1997, 350:422.

29. Malakooti MA, Biomndo K, Shanks GD: Reemergence of epidemic malaria in the highlands of western Kenya. Emerg Infect Dis 1998, 4:671-676

30. Lindblade KA, Walker ED, Onapa AW, Katungu J, Wilson ML: Highland malaria in Uganda: prospective analysis of an epidemic associated with El Nino. Trans R Soc Trop Med Hyg 1999, 93:480-487.

31. Lindblade KA, Walker ED, Wilson ML: Early warning of malaria epidemics in African highlands using Anopheles (Diptera: Culicidae) indoor resting density. J Med Entomol 2000, 37:664-674.

32. Minakawa N, Sonye G, Mogi M, Githeko A, Yan G: The effects of climatic factors on the distribution and abundance of malaria vectors in Kenya. J Med Entomol 2002, 39:833-841.

33. Minakawa N, Seda P, Yan G: Influence of host and larval habitat distribution on the abundance of African malaria vectors in western Kenya. Am J Trop Med Hyg 2002, 67:32-38.

34. Bodker R, Akida J, Shayo D, Kisinza W, Msangeni HA, Pedersen EM, Lindsay SW: Relationship between altitude and intensity of malaria transmission in the Usambara Mountains, Tanzania. J Med Entomol 2003, 40:706-717.

35. Zhou G, Minakawa N, Githeko A, Yan G: Spatial distribution patterns of malaria vectors and sample size determination in spatially heterogeneous environments: a case study in the west Kenyan highland. J Med Entomol 2004, 41:1001-1009.

36. Wrangham RW, Nishida T: Aspilia spp. leaves: A puzzle in the feeding behavior of wild chimpanzees. Primates 1983, 24:276-282

37. Wrangham RW, Goodall J: Chimpanzee use of medicinal leaves. In Understanding Chimpanzees. Edited by Harvard University Press. Cambridge. Heltne PG, Marquardt LA; 1989:22-37.

38. Huffman MA, Seifu M: Observations on the illness and consumption of a possibly medicinal plant Vernonia amygdalina (DEL.), by a wild chimpanzee in the Mahale Mountains National Park, Tanzania. Primates 1989, 30:51-63.

39. Jisaka M, Kawanaka M, Sugiyama H, Takegawa K, Huffman MA, Ohigashi H, Koshimizu K: Antischistosomal activities of sesquiterpene lactones and steroid glucosides from Vernonia amygdalina, possibly used by wild chimpanzees against parasite-related diseases. Biosci Biotech Bioch 1992, 56:845-846.

40. Huffman MA, Wrangham RW: Diversity of medicinal plants use by chimpanzees in the wild. In Chimpanzee Cultures. Edited by Harvard University Press. Mass: Wrangham RW, McGrew WC, de Wall FB, Heltne PG; 1994:129-148.
41. Ohigashi $H$, Huffman MA, Izutsu D, Koshimizu K, Kawanaka M, Sugiyama $H$, Kirby GC, Warhurst DC, Allen D, Wright CW, Phillipson D, Timon-David P, Delmas F, Elias R, Balansard G: Toward the chemical ecology of medicinal plant-use in chimpanzees: The case of Vernonia amygdalina (Del.). A plant used by wild chimpanzees possibly for parasite-related diseases. $J$ Chem Ecol 1994, 20:541-553.

42. Wrangham RW: Leaf-swallowing by chimpanzees, and its relationship to tapeworm infection. Am J Primatol 1995, 37:297-303.

43. Huffman MA, Page JE, Sukhdeo MVK, Gotoh S, Kalunde MS, Chandrasiri T, Towers GHN: Leaf swallowing by chimpanzees, a behavioral adaptation for the control of strongyle nematode infections. Int J Primatol 1996, 72:475-503.

44. Huffman MA, Gotoh S, Turner L, Yoshida K: Seasonal trends in intestinal nematode infection and medicinal plant use among chimpanzees in the Mahale Mountains, Tanzania. Primates 1997, 38:111-125.

45. Huffman MA, Caton JM: Self-induced increase of gut mobility and the control of parasitic infections in wild chimpanzees. Int J Primatol 2001, 22:329-346.

46. Krief $S$, Huffman M, Sévenet T, Hladik CM, Grellier P, Loiseau P, Wrangham RW: Bioactive properties of plants ingested by chimpanzees (Pan troglodytes schweinfurthii) in the Kibale National Park, Uganda. Am J Primatol 2006, 68:51-71.

47. Krief S, Wrangham RW, Lestel D: Diversity of items of low nutritional value ingested by chimpanzees from Kanyawara, Kibale National Park, Uganda: an example of the etho-ethnology of chimpanzees. Soc Sci Inform 2006, 45:227-263.

48. Krief S, Martin M-T, Grellier P, Kasenene J, Sévenet T: Novel antimalarial compounds isolated after the survey of self-medicative behavior of wild chimpanzees in Uganda. Antimicrob Agents Chemother 2004, 48:3196-3199.

49. Klein N, Fröhlich F, Krief S: Geophagy: soil consumption enhances the bioactivities of plants eaten by chimpanzees (Pan troglodytes schweinfurthii). Naturwissenschaften 2008, 95:325-331.

50. Blacklock B, Adler S: A parasite resembling $P$. falciparum in a chimpanzee. Ann Trop Med Parasit 1922, 16:99-106

51. Rodhain J: Les Plasmodium des anthropoïdes de l'Afrique Centrale et leurs relations avec les Plasmodium humains. Bull Acad Roy Med Belgique 1941, 6:21-60.

52. Bray RS: Studies on malaria in chimpanzees. III Gametogony of Plasmodium reichenowi. Ann Soc Belge Med Trop 1957, 37:169-174.

53. Ernst KC, Adoka SO, Kowuor DO, Wilson ML, John CC: Malaria hotspot areas in a highland Kenya site are consistent in epidemic and nonepidemic years and are associated with ecological factors. Malar J 2006, 5:78.

54. Struhsaker TT: Vocalizations, phylogeny and palaeogeography of red Colobus monkeys (Colobus badius). Afr J Ecol 1981, 19:265-283.

55. Chapman CA, Lambert JE: Habitat alteration and the conservation of African primates: case study of Kibale National Park, Uganda. Am J Primat 2000, 50:169-185.

56. Chapman CA, Wrangham RW: Range use of the forest chimpanzees of Kibale: Implications for the evolution of chimpanzee social organization. Am J Primatol 1993, 31:263-273.

57. Naughton-Treves L: Predicting patterns of crop damage by wildlife around Kibale National Park, Uganda. Conserv Biol 1998, 12:156-168.

58. Saitoh Y, Hattori J, Chinone S, Nihei N, Tsuda Y, Kurahashi H, Kobayashi M: Yeast-generated $\mathrm{CO}_{2}$ as a convenient source of carbon dioxide for adult mosquito sampling. J Am Mosquito Contr Assoc 2004, 20:261-264.

59. Gillies MT: The role of carbon dioxide in host-finding by mosquitoes (Diptera: Culicidae): a review. Bull Entomol Res 1980, 70:525-532.

60. Gillies MT, De Meillon B: The Anophelinae of Africa south of the Sahara (Ethiopian zoogeographical region), 2nd ed. South Afr Inst med Res Publ 1968, 54:1-343.

61. Snounou G, Singh B: Nested PCR analysis of Plasmodium parasites. Methods Mol Med 2002, 72:189-203.

62. Parsons RE Jr, Dondero TJ, Hooi CW: Comparison of CDC miniature light traps and human biting collections for mosquito catches during malaria vector surveys in peninsular Malaysia. Mosa News 1974, 34:211-213.

63. Chandler JA, Hill MN, Highton RB: The use of light traps for long-term surveillance of mosquitoes of epidemiological importance on the Kano Plain, Kenya. East Afr Med J 1976, 53:596-600.

64. Okello PE, Van Bortel W, Byaruhanga AM, Correwyn A, Roelants P, Talisuna A, D'Alessandro $U$, Coosemans M: Variation in malaria transmission 
intensity in seven sites throughout Uganda. Am J Trop Med Hyg 2006, 75:219-225.

65. Karch S, Mouchet J: Anopheles paludis, vecteur important du paludisme au Zaïre. Bull Soc Pathol Exot 1992, 85:388-389.

66. Parent M, Vincke I: Notes entomologiques (Diptera: Anophelinae). III. Rec Sci Med Congo Belge 1945, 4:23-24.

67. Lambrecht FL: Anopheles (Christya) implexus, Theobald. Description de la variété locale de la vallée du Mosso (Urundi). Rev Zool Bot Afr 1954, 50:204-209.

68. Barber MA, Olinger MT: Studies on malaria in Southern Nigeria. Ann Trop Med Parasit 1931, 25:461.

69. Haddow AJ, Van Someren ECC, Lumsden WHR, Harper Jo, Gillet JD: The mosquitoes of Bwamba County, Uganda. VIII. Records of occurrence, behaviour and habitat. Bull Ent Res 1951, 42:207.

70. Hanney PW: The mosquitoes of Zaria Province. Northern Nigeria. Bull Ent Res 1960, 51:145.

71. Hervy JP, Le Goff G, Geoffrey B, Herve JP, Manga L, Brunhes J: Les Anophèles de la région afrotropicale, Logiciel d'identification et d'enseignement trilingue. Paris: ORSTOM/OCEAC; 1998.

72. Brooker S, Clarke S, Njagi JK, Polack S, Mugo B, Estambale B, Muchiri E, Magnussen $P$, Cox J: Spatial clustering of malaria and associated risk factors during an epidemic in a highland area of western Kenya. Trop Med Int Health 2004, 9:757-766.

73. Furuichi T, Hashimoto C: Botanical and topographical factors influencing nesting-site selection by chimpanzees in Kalinzu Forest, Uganda. Int $J$ Primatol 2004, 25:755-765.

74. Brownlow AR, Plumptre AJ, Reynolds V, Ward R: Sources of variation in the nesting behavior of chimpanzees (Pan troglodytes schweinfurthii) in the Budongo Forest. Am J Primatol 2001, 55:49-55.

75. Stewart FA, Pruetz JD, Hansell MH: Do chimpanzees build comfortable nests? Am J Primatol 2007, 69:930-939.

76. Baldwin PJ, Sabaster PJ, McGrew WC, Tutin CEG: Comparison of nests made by different populations of chimpanzees. Primates 1981, 22:474-486.

77. Wolfe ND, Kilbourn AM, Karesh WB, Rahman HA, Bosi EJ, Cropp BC, Andau M, Spielman A, Gubler DJ: Sylvatic transmission of arboviruses among Bornean orangutans. Am J Trop Med Hyg 2001, 64:310-316.

78. Chapman CA, Chapman LJ, Zanne AE, Poulsen JR, Clark CJ: A 12-year phenological record of fruiting: Implications for frugivore populations and indicators of climate change. In Tropical Fruits and Frugivores. Edited by Dew JL,Boubli J. Netherlands: Springer; 2005:75-92.

doi:10.1186/1475-2875-11-116

Cite this article as: Krief et al.: Investigations on anopheline mosquitoes close to the nest sites of chimpanzees subject to malaria infection in Ugandan Highlands. Malaria Journal 2012 11:116.

\section{Submit your next manuscript to BioMed Central and take full advantage of:}

- Convenient online submission

- Thorough peer review

- No space constraints or color figure charges

- Immediate publication on acceptance

- Inclusion in PubMed, CAS, Scopus and Google Scholar

- Research which is freely available for redistribution

Submit your manuscript at www.biomedcentral.com/submit
() Biomed Central 